\title{
ECONOMICS
}

\section{Paretian Fiscal Sociology}

Michael McLure

University of Western Australia 


\title{
Paretian Fiscal Sociology
}

By

Michael McLure

\begin{abstract}
This work is a draft chapter for the forthcoming book "James Buchanan: A Theorist of Political Economy and Social Philosophy”, which is being edited by Ricard E Wagner for Palgrave Macmillan. It considers Pareto's treatment of fiscal issues, first as a middle age economist and subsequently as a mature age sociologist. It establishes that Pareto never regarded fiscal studies as a purely theoretical exercise. Even as an economist, he relegated 'fiscal effects' to the aspect of applied economics that he called the 'concrete economic phenomenon'. Pareto's fiscal sociology takes his observations from applied economics and subjects them to further analysis using his division between logical and non-logical action, with fiscal effects falling within the category of non-logical action. This chapter reviews those enhancements and subjects Paretian fiscal sociology to critical assessment. While the Paretian episode in fiscal sociology has now long passed, the study concludes by noting a number of its attributes that have continuing relevance.
\end{abstract}

Key Words: Buchanan, Pareto, Public Finance, Sociology

JEL Code: B13 


\section{Introduction}

The intellectual relationship between Vilfredo Pareto and James Buchanan is bifurcated in relation to issues of collective action. On one side, Pareto's name is associated prominently with ideas that Buchanan either reacted against or qualified so substantially that their meaning was substantially altered. But on the other side, there is a remarkable complementarity between Pareto's treatment of the 'concrete phenomenon' and collective action and the choice tradition.

In terms of contrast, Pareto laid the foundation for the first and second laws of welfare economics as it applies to outcomes using the criterion that we now associate with Pareto optimality. Pareto also formalised the idea of ranking for welfare assessments (Pareto 1900a [2008]), with Pareto's contributions to the economics of welfare and ordinalism becoming cornerstones for Social Choice and its focus on different social states or outcomes. Buchanan (1962), however, used the criterion of Pareto optimality in relation to processes and rules rather than outcomes. Pareto (1913 [1980]) also introduced the notion of social utility as a basis for his development of a social welfare function, with a view to investigating issues associated with maximising social utility (Pareto 1913). The very notion of social utility is, however, a far cry from Buchanan’s rigorously individualistic approach to collective action.

But in his treatment of the 'concrete phenomenon', Pareto's critical, sober and almost Machiavellian account of politics, and political processes, are consistent with the analysis of politics associated with public choice. This was evident in many of Pareto's brutal and critical commentaries on Italian politics, published in the Giornale degle Economisti in the mid-1890s under the banner of Cronaca (Chronicle). But it is most fully articulated in Pareto's studies of the 'concrete economic phenomenon' in his Manual of Political Economy (1906 \& 1909 [2014]). And even the sociological work of older Pareto, who, in the early twentieth century had lost faith in the possibility that individual liberty would prevail over special interest in the sphere of politics, includes public choice elements. As was first made clear by Jürgen Backhaus (1978), Pareto’s sociology of public finance is primarily a study of 'non-logical' action, which is not a specific methodological claim of public choice.

Buchanan himself appeared to be more inclined to accentuate the theoretical than the concrete aspects of Pareto's work as he did not attempt to associate his own work with those aspects of Pareto's approach, or that of the Paretians, that resonate with the public choice 
approach. Moreover, he distanced himself from Pareto by underlining the point that, as advocates of a sociological approach to the study of public finance, Pareto, and his follower Gino Borgatta,

"reject any attempt to use economic analysis in the explanation of fiscal activity. To Pareto and to Borgatta, state decisions are made by a different sort of calculus, and there is no such thing as a 'science of finance' analogous to economic science. The explanation for fiscal activity should be sought instead in the murky science of sociology. (Buchanan, 1960, p. 36) ${ }^{1}$

In this chapter I seek to honour the memory of James Buchanan by clarifying the meaning of Pareto's fiscal studies. Consideration is given to what 'Pareto the economist' and what 'Pareto the sociologist' had to say on the topic. The Chapter is structured in three parts. Part 1 deals with 'Pareto the economist' and how he treated fiscal arrangements within the subject of economics. Attention is given to Pareto's articles Cronaca for the Giornale degli Economisti and his application of the idea of successive approximations when placing fiscal phenomena within the overall context of the economic phenomena. His most mature 'economics of public finance' emerges, not in economic theory, but in his applied treatment of the 'concrete economic phenomenon'. Part 2 deals with 'Pareto the Sociologist' and the role of his distinction between 'logical' and 'non-logical' action in his mature study of public finance, policy and welfare. The mature work of Pareto culminates in the emergence of a fiscal sociology, one which was subsequently adopted and developed in Gino Borgatta (1920) and Guido Sensini (1932). The Chapter concludes with a discussion of the current relevance of Paretian fiscal sociology, in part or in whole. It is, among other things, suggested that Paretian fiscal sociology can be viewed as a companion to the modern, public choice inspired, variant of fiscal sociology that emerged in Richard Wagner’s (2007) exploratory essay.

\section{Part 1: Pareto 'the Economist'}

\footnotetext{
${ }^{1}$ The two classic accounts of the Italian fiscal tradition are Mauro Fasiani's "Der gegenwärtige stand der reinen theorie der finanzwissenschaft in Italien” (1932-33 [1980]) and James Buchanan's "'La Scienza delle Finanze': The Italian Tradition in Fiscal Theory" (1960). Fasiani’s influence on Buchanan's thinking about the Italian fiscal tradition is readily evident from his paper, including his acknowledgement of Fasiani, but there is a significant difference in their respective assessments of the Paretians. Fasiani, in the abovementioned paper and in a subsequent work (Fasiani 1949), was much more appreciative of Pareto’s sociology than was Buchanan.
} 
Pareto's long association with the Giornale degli Economisti started in the years between his career as the managing-director of an iron works company, which ended in 1890, and his academic career at the University of Lausanne, which commenced in 1893 . While his early contribution to that journal featured works on pure economic theory (Pareto 1892-93 [2007]), those contributions soon broadened to include practical commentaries on Italian politics and public finances as the author of the Journal's Cronaca between 1893 and 1897. The context for many of Pareto’s ‘chronicle’ articles concerned the role of government in Italy, at a time when Italy's national governments were active in catching up with the other major European powers in regard to industrialisation and the development of colonial empires (McLure 2010).

As a result, many issues presented in Pareto's chronicles concerned 'protection' for the purposes of fostering industrialisation in general, protection and public spending to enhance Italy’s naval capabilities by subsidizing the development of defence industries, the expense of colonial activities, public spending and the size of government generally, and taxation and debt. He was, by and large, a critic of the government on all these issues. Perhaps the main analytical theme underlying his comments concerned the broader cost to the society of providing benefits through political patronage. The basic fiscal attribute of Italian government decisions is that the interaction between revenue raising, debt and public spending involves transfers of funds from one part of society to another part.

The political dimension to collective decisions that reward patronage via a fiscal process reflects some of the political realism of what is now known as public choice. Buchanan, of course, stripped the romance from the discussion of democracy by shifting his focus on the transactions undertaken by governments. This too is reflected in Pareto's chronicles but, unlike public choice, Pareto did not attribute this to the institutional context by which individual interest is pursued in political environment. Rather, the sarcasm and harshness of Pareto's assessment in his chronicles are indicative of a contempt for the selfinterest of politicians and a moral outrage at the patrons-client relationships between government members and special interests outside parliament. He sought to expose such action and persuade others that such action is being undertaken at the expense of the general good. In that regard, Pareto of the 1890s is a committed radical liberal who regards laissezfaire as the best starting point for policy considerations. 
In his first major book, the Cours d'Économie Politique (Pareto 1896-97 [1971]), Pareto constructs a framework based on the notion of successive approximations in which political influences on the economy, transmitted via fiscal and monetary influences, fall outside the 'first' approximation to the economic phenomenon. The first approximation is reserved for 'pure' economics, which is fundamentally Walras's theory of general equilibrium, with the equilibrium state being the primary phenomenon of economics. All other aspects of the economic phenomenon, including the influence of public choices on collective decsion making, fall to the second approximation provided by applied economics. When the economic phenomenon is also influenced by broader social phenomena, insights from the other discplines of the social sciences - be it politics, law or sociology - it is then necessary to derive a third approximation to the economic phenomenen which accounts for interactions between the laws of pure and applied economics and the laws established in the other social sciences.

For the purposes of this Chapter, the main implication to be drawn from Pareto's successive approximation approach is that fiscal decisions are a subject for the second and third approximations to the economic phenomenon. The state of the economic equilibrium is the primary phenomenon of economics, and it is studied with respect to voluntary choice predicated on an initial allocation. In the phraseology of Pareto’s Manual, it was a balance between forces associated with 'tastes' to be satisfied and 'obstacles' to their satisfaction, such as budget constraints, production constraints, and the impact of the demand of others. As fiscal decisions are not the result of voluntary actions and give authority to alter the initial allocations, they are excluded from Pareto’s first approximation. A similar situation applies to the relationship between politics and fiscal decisions in Pareto's sociology. According to his political sociology of elites, which emerged in comprehensive and coherent forms in “Un’Applicazione di Teoria Sociologiche (An Application of Sociological Theory) ” (Pareto 1900c [1980]) and Les Systèmes Socialistes (The Socialist Systems) (Pareto 1902 [ 1974]), fiscal issues are secondary to the primary political phenomenon, which concerns the transitory character of political authority because elites 'rise and fall'. The fiscal arrangements are considered at the level of the second approximation, as one of the instruments that a ruling elite uses in the context of patron client relations. To the sociologist, fiscal arrangements are significant for the light they shed on the stability of the political equilibrium, when elites endure, and instability in the political equilibrium, when the continuity of existing elites is threatened or ends. 
But, irrespective of his assignment of fiscal arrangements to the second or third approximations for the purposes of general social science, Pareto's economic discussion of fiscal issues in the concrete context remains insightful. This is perhaps most important in Chapter IX of the Manual, "The Concrete Economic Phenomenon”, which asserts that “writers who discuss 'fiscal equity’ are mere dreamers; so far, no such thing has ever been seen in the whole wide world" (Pareto 1906, 1909 [2014, p. 238]) because "the economic phenomenon always tends to be governed by the interests those classes of society which predominate in the government” (Pareto 1906, 1909 [2014, p. 239]). In other words, the realpolitik presented in Cronaca is retained, but, by the early twentieth century, Pareto's hope for improved action by politicians had been replaced by a brutal, largely positivist, recognition that self interest lies at the heart of the political phenomenon and that this must be incorporated directly within theory when considering the relationship between fiscal choices and the broader economic and political phenomena.

In that regard, Pareto was aware of Australia's Customs Tariff Act 1906, which imposed tariffs on the importation of agricultural machinery, and Excise Tariff Act 1906, which imposed an excise tax on Australian manufacturers of agricultural machinery that did not pay employees a 'fair and reasonable' wage, as determined by the Parliament or the Courts.

“[Australian] manufacturers of agricultural machinery have been granted a prohibitive tariff against the import of American machinery, but on the condition that if they do not pay 'fair and reasonable' wages to their workers, they will have to pay an amount on their products equal to one half the duties imposed by the customs tariff” (Pareto 1909 [2014, p251]).

Pareto's general point is that a new equilibrium will be attained under such policy, but some groups must be harmed under this new equilibrium because an advantage given one is necessarily a disadvantage for everyone else. In this specific case, the new equilibrium yields a benefit for some Australian workers (those who work in the Australian agricultural machinery industry and obtain 'fair and reasonable’ wages ${ }^{2}$ ) and some Australian

\footnotetext{
${ }^{2}$ When hearing this matter, Justice Henry B. Higgins, President of the Commonwealth Court of Conciliation and Arbitration (and formerly a Member of the Australian Parliament for the 'Protectionist Party'), ruled that the "provision for 'fair and reasonable' remuneration ... must be meant to secure to them [employees in the industry] something which they cannot get by the ordinary system of individual bargaining with employers.... The standard of 'fair and reasonable' must therefore be something else, and I cannot think of any other standard appropriate than the normal needs of an average employee, regarded as a human being in a civilised community." (Higgins 1907, p.3) From that principle, Higgins ruled on the value of a fair and reasonable wage rates for the purposes of the Act.
} 
entrepreneurs and some owners of capital (those in the agricultural manufacturers that pay 'fair and reasonable' wages), but it imposes a cost on all other entrepreneurs and capitalists (those not in the agricultural machinery business), all other workers or would be workers (those not employed in the agricultural machinery industry) and, of course, all consumers.

For the study of public finance, the issue foremost in Pareto’s mind was that fiscal policy is the primary instrument through which a desired redistribution of income, concurrent with the consequent 'destruction of wealth', creates economic privileges or rents for a protected class of individuals at the expense of others in society: "protection does not present itself in pure form, but is always bound up in fiscal measures” (Pareto 1906, 1909 [2014, p. 262]). This example also indicates the tension between the normative goal (such as 'fair and reasonable' wages in the agricultural machinery sector) and the positive effects of realizing a particular normative goal (such as a reduction in the real income of all other workers).

But to complement, and perhaps to offset, his highly critical views on public finance, Pareto also laid the foundation for the New Welfare Economics that we typically associate with Sir John Hicks. Most important in that regard was his first paper on welfare economics, “The Maximum of Utility given by Free Competition” (Pareto 1894 [2008]). This paper is important for several reasons. First, it provided the basic framework by which value judgements are largely removed from economic consideration. Specifically, value judgement is retained as legitimate in economics up to the point where an increase in aggregate output is recognised as desirable provided no one is harmed by the increase or, if any individuals are harmed, then the collective has the capacity to compensate those individuals who are harmed. Secondly, value judgements that suggest that any redistribution of product is desirable lie outside the scope of economics. That role is allocated to the "Ministry of Justice".

The economic issue of importance to Pareto was how any such redistribution should be effected, not the extra-economic question of what the redistribution should be. Specifically, if the Ministry of Justice concludes that the income of workers must rise to achieve distributive justice, should that be achieved by increasing wage rates to levels above those attained in equilibrium under free competition?

Pareto's answer was an unequivocal no because the utility (profit) maximising producer will reduce the co-efficient of production for labour (use less labour in the production of each unit of output due to the increase wage) and increase the coefficients of production for the other 
factors of production (more non-labour factors of production used in the production of each unit of output), which increases the unit cost of production and reduces the real value of aggregate production compared to that obtained under free competition. Invoking the compensation principle, he argued that policy to maximise the real value of output from resources is always the correct goal for the Ministry of Production (a public body with policy authority over factor prices) to aim for. When the Ministry of Justice has particular goals for distributive justice that are inconsistent with factor prices that maximise output, efficient factor prices can be maintained and non-distorting transfer payments can be introduced to achieve the redistributive goal. As such, 'pure protection' of the poor associated with action of the Ministry of Justice depends on transfer payments being funded from taxes that do not disturb the coefficients of production (i.e. taxes that don't distort the distribution of income).

In subsequent work, Pareto set about introducing ordinal analysis to the formal pure theory of economic equilibrium, in "Summary of Some Chapters of a New Treatise on Pure Economics” (Pareto 1900 [2008]), and extending and systematically generalising what may be termed the 'laws of welfare economics' approach in "On a New Error in the Interpretation of the Theories of Mathematical Economics” and the Manual (Pareto 1906-09 [2014]).

\section{Part 2: Pareto 'the Sociologist'}

Pareto 'the sociologist' does not repudiate the views of Pareto 'the economist' on the fiscal phenomenon. The characterization of fiscal effects presented in his "The Concrete Economic Phenomenon" is embraced by his sociology, not denied by it. What Pareto the sociologist tried to do was to provide a more nuanced and comprehensive explanation of the phenomena than he had previously attained through applied economics. And it was the distinction between 'logical' and 'non-logical' action, which Pareto first introduces in "Sul Fenomeno Economico” (1900b), that provides the key to Pareto’s shift to fiscal sociology.

The distinction between logical and non-logical action was partly introduced because of his dissatisfaction with another author's distinction between 'logical' and 'illogical' action. This is important because it underlines the point that Pareto's non-logical action does not extend to illogical action. Rather, non-logical action is simply action motivated by feelings or sentiments, which largely defy objective characterization. He first defined his theory of action in "Un’Applicazione di Teoria Sociologiche” (Pareto 1900c [1980]), with the logical or non-logical division of action considered with respect to the relationship between the 
subjective assessment of the phenomenon associated with action and an objective account of that phenomenon. Specifically, action is 'non-logical' when the a priori subjective assessment of the expected objective outcome of action and the a posteriori subjective assessment of that objective outcome are different, which reveals an interdependence between the subjective and objective forms of a phenomenon. Logical action, in contrast, reveals a consistency between an expected outcome and the a priori and ex post subjective assessment of that objective outcome.

In the Manual, Pareto discussed non-logical action at some length, but primarily for the purposes of deliberately excluding such action from pure economics. He revisited the issue again in some detail in 'Le Azioni Non Logiche’ (1910), which was a preparatory work for his definitive characterization of the distinction between logical and non-logical action outlined in the Trattato di Sociologia Generale (Pareto 1916 [1935]). There are several dimensions to Pareto’s final distinction between logical and non-logical action in that work, but, at the most fundamental level, it can be reduced to two relationships: (i) the nexus between means and an end; and (ii) the relationship between the objective and the subjective forms of the end being pursued.

A logical nexus between the means applied to achieve an end and the achievement of that end is a necessary and sufficient condition for Pareto’s logical action. But a logical means-end nexus is only possible when the subjective assessment of the end of an action, or of a series of actions (the subjective end), is identical to, or perfectly conformed to, the objective form of the end that is undertaken by an action or a series of actions (the objective end). In modern parlance, we could say that Pareto's logical action is equivalent to decisions made within a path independent utility field. No matter what location a person is within his or her utility field, the dimensions of which are defined by quantities of commodities, the expected utility maximization given at any particular coordinate will be attained by simply moving to that point. And his conception of non-logical action is largely equivalent to decisions made with reference to a path dependent utility field. In that case, one's assessment of utility changes with movement in utility space, so subjective assessment of utility maximization at a particular coordinate will alter when moving to other points in the utility space, thereby precluding a logical means-ends nexus.

Voluntary choice in markets falls within the scope of Pareto's logical action, at least as a first approximation. Specifically, at the level of first approximation, exchange and 
production are the outcome of logical action. As a result, market phenomena can be considered with respect to the idea of an economic maximum. But Pareto did not regard fiscally directed activities that impact the economic equilibrium as falling within the category of logical action. There is an attempt to align fiscal means with policy ends in an efficient manner, but the subjective perspective of the policy end and the objective form of that policy end are typically not perfectly conformed. Each individual engaged in non-logical action may regard his or her actions as logical because means are employed logically to achieve the desired end and because, a priori at least, he or she does not recognize that the ex post subjective assessment of the objective end will be different from that subjective assessment $a$ priori.

For politically directed collective action, the interconnected points in the means-end chain are prolonged and encompass actions by many different individuals acting within different groups. Material interest may well be at the heart of many political actions that culminate in fiscal decisions, but consistency of choice is not reflected in actions of individuals that form groups to govern, let alone for those governed. Given all the complexities of the extended political means-end chain that is facilitated through public finances, the fundamental, and perhaps the defining, feature of fiscally directed political action in Pareto's assessment is its non-logical character - the difficulty of applying a logical means-ends relationship to fiscal choices.

In regard to the positive aspect of fiscal action, Pareto the sociologist reprised the issue of patron-client relationships and fiscally inspired redistribution by political elites to reward supporting economic elites. The objective outcome is a fiscally directed redistribution of income from the many to the few. On this issue Pareto made an important point in his first major book on sociology, Les Systèmes Socialistes, that anticipated a fundamental underlying proposition of Mancur Olson's The Logic of Collective Action (1965):

"There is a curious circumstance, which warrants attention: one often observes that men act with much more energy to appropriate the goods of others than to defend their own goods. ${ }^{3}$ In a country of thirty million inhabitants, suppose that, under some pretext, it is proposed that each citizen be made to pay one franc per year and to distribute the total sum to thirty people. Each of the despoiled people pays one franc, each of the people doing the despoiling receives one million. The actions of the two

\footnotetext{
${ }^{3}$ After the first sentence of this quote, Pareto is citing his own numeric example from the Cours (1896-97 [1971, p. 1086-1089]).
} 
parties [in relation to the proposal] will be very different. The people who hope to earn a million a year will never rest, by day or by night. .... On the side of the people being despoiled, activity will be much less. Money is needed to undertake an electoral campaign, which presents insurmountable material difficulties because they would have to go to each citizen and ask for a few cents.” (Pareto 1902 [1974, p226])

Pareto's sociology is an attempt to establish the regularities of the non-logic of collective action ${ }^{4}$, including when that action is directed to the material welfare of subsets of individuals of society. New equilibrium states associated with an implemented public policy proposal need not have been reached by logical means, for reasons already mentioned, and those who gain do so at the expense of others. That is essentially a restatement of Pareto 'the economist' to account for non-logical actions. But Pareto 'the sociologist' would also add that the extent of any gain (or loss) realized depends on sociological influences. Specifically, it depends on the success, or otherwise, of manifestos or policies designed to persuade the public that they should support a specific proposal; and manifestos are only effective at persuading when they blend quasi-logic with a good deal of the value laden terms that have no precise objective meaning.

Consequently, non-logic not only takes prime place for the theory of action, it also takes prime place for understanding the processes by which people are persuaded to accept policies, even if those policies result in loss for those being persuaded. Pareto referred to such manifestos or doctrines as 'derivations'. They are effectively doctrines in which logic is interrelated with sentiments that the authors either hold to be true or trust that others hold to be true and, therefore, helpful in securing public support for the proposed outcome. Once the strictly logic aspects of a ‘derivation’ has been stripped away, a 'residue’ remains which is a statement or expression of sentiment, or a combination of sentiments, that social scientists can identify. The greater the extent to which a fiscal outcome depends on the use of a 'derivation' and 'residues', the lesser it can be suggested that that outcome is the result of a strictly logical process.

The net effect of the above is that, while the motivation for fiscal action may be the same as that adopted in economics (gaining a material benefit), the means of obtaining that benefit are non-logical. Borrowing Busino’s phrase, a good politician or political advisor

\footnotetext{
"Giovanni Busino suggests that Pareto is, in his sociology, concerned with "discovering the logic of non-logic" (Busino 1994, p. 10). In relation to public finances, that means that Pareto's fiscal sociology is concerned with discovering the logic, in the form of general regularities and uniformities, of fiscally directed redistributions (including debt as a fiscal device that redistributes income) for that does not comply with the strict meaning of a logical means-ends relationship, along the lines defined earlier in this Chapter.
} 
must draw on the 'logic of non-logical' reasoning when developing derivations designed to persuade through 'spin'. As a consequence, Pareto favored a sociological approach to the study of public finances. Indeed, his position on this matter was so strong that he was openly hostile to the very idea of an economics of public finance. It is now well understood that the early marginalist Italian literature on 'public goods', which was literally referred to in Italian as 'public needs', was much more advanced at the time than it was in the contemporaneous English literature. ${ }^{5}$ But Pareto saw no scientific merit in any of that literature, nor in any of the burgeoning Italian literature on the Ricardian equivalence between taxation and public debt, nor in any of the general Italian literature seeking to develop an economic science of public finance. $^{6}$

Sociological forces associated with fiscal decisions were also significant to Pareto because they adjust the prediction of economic laws. Pareto's own work on the first law of welfare economics indicated that a destruction of wealth (i.e. reduction in the value of production) results when the relative prices of the factors of production are changed from those prevailing under free competition. But when the non-logical basis of collective action is considered, Pareto recognized that fiscal redistribution places capital in the hands of others. He recognized that the destruction of wealth that initially results from the economic effects of fiscal redistribution may, indirectly, be more than fully offset by the sociological consequences of fiscal redistribution. The difficulty, however, was that these sociological results were indeterminate. The destruction of wealth from protection may be aggravated further by the sociological consequences of fiscal redistribution, it may be unaffected by the sociological consequences of fiscal redistribution and it may be partially, fully or more than fully offset by the sociological effects. To get a handle on this problem, Pareto distinguished between rentiers and speculators and asked whether fiscal redistribution would increase or decrease the value of capital in the hands of those two groups.

Rentiers are presented by Pareto as timid and cautious when: holding money (by accepting low interest rates when holding money safely and typically being unwilling to borrow); undertaking entrepreneurial activity (by undertaking secure low risk activities); being employed as a worker (by seeking tenured employment with lower remuneration for lower risk); accumulating capital (by acquiring capital goods with values that don't fluctuate

\footnotetext{
${ }^{5}$ See Fausto (2006) and Fossati (2006).

${ }^{6}$ A detailed account of Pareto's reaction against the economics of public finance can be found in McLure (2007).
} 
over time so depreciation can be managed and replaced in an ordered manner); holding land (by seeking low long term returns). The unifying factor is, of course, that rentiers seek very limited exposure to risk in all the economic activities they undertake. They reveal, in other words, a low discount rate. Conversely, speculators are presented by Pareto as being willing to accept high risk in all the economic activities they undertake. In effect, they reveal a high discount rate. In that regard, speculators are vigorous and active when: holding money (by seeking high returns and capital gains from financial assets and being more than willing to borrow); undertaking entrepreneurial activities (by being innovative by combining capital goods to create new products and/or seeking rents through strategic pricing and exploiting monopoly power); accumulating capital (by seeking capital gains, even in the short term); and holding land (by high returns and capital gains).

Transferring income between rentiers and speculators may have obvious short term implications. It may either exacerbate or smooth business cycles, depending on the direction of the transfers. But Pareto also saw such transfers as having longer term implications. The great prosperity of the nineteenth century associated with the effects of the industrial revolution was, in Pareto's assessment, largely due to the combined effect of a large share of productive capital being placed in the hands of speculators at the same time as when a large proportion of the masses of the population are rentiers seeking employment as workers. Speculation and innovation are correlated and linked to increasing prosperity, provided there are enough rentiers for the financial system to fund the speculators; and a good proportion of the workforce is employed in the innovation oriented firms controlled by speculators.

Pareto, however, did not limit his study of collective action to individuals acting within the political institutions of the collective to achieve personal economic gain. His sociology also accounts for altruistic and even paternalistic motivations associated with nonlogical action. For example, one may associate a particular a priori objective end with the subjective end of 'distributive justice', but once the objective state is altered to attain that objective end, one may no longer regard it as representing a state of 'distributive justice' because the objective end and the subjective end are interdependent such that a stable equilibrium is not attained.

But Pareto also recognized that the individuals who comprise the collective are heterogeneous. Not only do individuals act differently - with some people initiating new activities, others repeating routine activities and a distribution of behaviors in between those 
two extremes; and some people acting to introduce change to the prevailing social state, others acting to preserve the existing social arrangement plus a distribution of individual behaviors between those two extremes - they also have different views about the welfare of other members of the collective. To the positivist in Pareto, this presented a serious methodological problem. Firstly, 'social' preferences, or preferences that individuals hold in relation to the welfare of other members of the collective, cannot be readily observed. Not just because action is non-logical, but because each individual's social preferences cannot be observed and even if they could, they would change with objective circumstances. Furthermore, action regarded as leading to a 'just' distribution of income, or some other social goal, is undertaken by the institutions of the state, not by individuals themselves.

Recognition of this had two implications for Pareto. First, and most significantly from the perspective of positive science, sentiment pertaining to the wellbeing of others can be readily exploited politically by groups acting politically who are acting in the economic interest of themselves. That is, it may culminate in persuasive 'derivations', as discussed earlier. Second, to the extent that sentiment pertaining to the wellbeing of others is significant, the economic maximum of the collective obtained under the first law of welfare economics will not be a maximum when utility is social.

In regard to the first point, consider the 1907 Australian case of tariff and excise on agricultural machinery mentioned earlier. That was a policy presented as a mechanism for improving the living standard of the working people. But, within Pareto's Fiscal sociology, that was a subjective assessment designed to persuade; whereas the objective end is a negative sum policy game (i.e. wealth is destroyed) that enhances the material wellbeing of workers, capitalists and entrepreneurs within one industry (domestic producers of agricultural machinery) while reducing the material wellbeing of workers, capitalists and entrepreneurs in all other industries.

But the existence of preferences for social outcomes also means policy to maximize economic outcomes on the assumption that all individuals are homo ceconomicus will not be welfare maximizing in a social sense. In view of this, Pareto reflected on what a political group might do if its goal was to devise a policy that actually maximizes welfare in a sociological sense. To that end, he specified a two-step process by which a Government that truly wishes to maximize the welfare of the collective could do so. First, the government must know each individual's social utility function. In practice, this means that it must 
establish how much weight each individual assigns to the welfare of every individual within the collective. Second, the government would then weight, discriminatingly, each individual's social utility function to derive a social utility function. The result will, of course, change with government. In effect, the government acts this way to impose a social utility function on the community from which a logical nexus between the subjective end of policy, of maximizing social utility, and the objective outcome associated with that subjective end, can be derived.

The overall scheme of Pareto's sociology is united under the concept of 'social equilibrium', the internal elements are given by the interrelationship between a number of key elements: residues, derivations, heterogeneity (i.e. the distribution of people within a society is characterized by heterogeneity), economic interests and elites (i.e. people within a society tend to form groups, with the best elements within those groups emerging as elites). But that is a rather abstract formulation that tends to conceal the significance of Pareto's notion of social equilibrium. To modern scholars, it is perhaps simpler to view Pareto’s notion of 'social equilibrium' as an overarching concept that is, itself, comprised of three subcategories of equilibria: a 'political equilibrium', which is the balance in the collective obtained between the individualism and collectivism; an economic equilibrium, which concerns the balance in the collective between producing wealth and appropriating wealth produced by others; and a socio-behavioral equilibrium, which concerns the balance in the collective between the forces of social continuity and the forces of social change.

Significantly, the political and economic equilibria of Pareto's social equilibrium are interdependent, with the role of political elites in achieving a balance between individualism and collectivism interrelated with the role of economic elites in producing wealth or appropriating it for others. As such, the variable aspects of social equilibrium are associated with the interplay between the political and economic equilibria, through the interplay between agents of the political elite and agents of the economic elite. The socio behavioral equilibrium, however, is much less variable because it is constrained significantly by residues that favor continuity or change, with the distribution of those residues largely given by people’s psychological make up and, as such, a force for continuity.

The evolution of the social equilibrium is largely a result of the equilibrium becoming unstable, with competition between competing economic and political elites resulting in a new equilibrium emerging in conjunction with the circulation of elites. That is, with the 
change of government and the change of patron client relations, with the rentiers and speculators assuming greater or lesser roles under each state of social equilibrium. The form of the social equilibrium may change, with new institutions emerging or the significance of existing institutions changing, but there is a socio-behavioral floor under such change given by the distribution of individual psychological propensities for continuity or for change.

\section{Part 3: On the Current Relevance of Paretian Fiscal Sociology}

The Paretian episode in fiscal sociology had ended by the 1930s and, if a case is to be presented in favor of the current relevance for Paretian fiscal sociology, one must first establish why it ended. In that regard, the great problem it failed to successfully address was not the rationale for introducing non-logical action to the analysis of fiscal studies per se. Indeed, modern studies of path dependence and independence in economics serve to underline the relevance of Pareto's analytical dualism. Rather, it concerned the extent to which regularities could be generalized in a way that altered or qualified economic conclusions. ${ }^{7}$ For a start, much of Pareto's applied economic treatment of 'the concrete economic phenomenon' is reflected in his fiscal sociology. Consequently, some of the results of fiscal sociology, based on non-logical action, don’t change from early analysis that predates the focus on non-logical action. For example, although Pareto's general theory of social equilibrium indicated that fiscal redistribution could destroy wealth, as predicted in economics generally and Pareto’s economics more specifically, the sociological effects could be change in anything depending on the circumstances. Using an analogy with statistics, the introduction of a sociology of public finance was sometimes regarded as akin to an analysis of 'statistical noise'. Such criticism goes too far because it does not account for Pareto's discussion of the role of rentiers and speculators in generating regularities associated with fiscal redistribution.

Nevertheless, it must be accepted that the success of Pareto and his followers in generating fiscal regularities through sociology was limited. When it was attained, it was typically at very high levels of generalization. This suggests that perhaps the greatest potential value of a modern Paretian fiscal sociology would be in the area of applied fiscal

\footnotetext{
${ }^{7}$ The Paretian episode in fiscal sociology and its end is discussed by McLure (2007); and the relevance of that episode for historians is examined very thoughtfully by Italo Magnani (2008).
} 
studies, such as national and subnational fiscal histories (although no major studies along that line have been undertaken thus far). But it would also, I believe, be wrong to close the book completely on Paretian fiscal sociology for offering nothing of relevance for current fiscal theorists. In my assessment, there are four main reasons why some aspects of Paretian fiscal sociology have current relevance.

First, the motivation for Pareto's initial rejection of the economics of public finance in the case of Ricardian equivalence is of continuing importance as it underlines the proper scope of fiscal theory. In particular, Pareto regarded the prevailing mix of debt and taxation as the means by which a government can spend more than if it relied on taxes alone. Comparing the economic effects of raising a 'given' sum of money by one means or another appeared pointless to him, when direct observation confirmed that government revenue raising is not a case of 'either' tax 'or' debt, but a case of how much can be obtained when both methods are used. He also regarded the characterization of taxpayer/saver/consumer as logical in an intertemporal (and intergenerational) manner as fundamentally flawed because it imposes a standard of behavior that is not observed. The first of these points not only has relevance for modern treatments of Ricardian equivalence, it also has relevance for any form of public finance analysis that seeks to consider the revenue side of the budget as something that is separate from the expenditure side of the budget. If nothing else, Paretian fiscal sociology underscores the interdependence between revenue funding and expenditure decisions as fiscal redistribution is a net concept, because governments typically wish to increase expenditure. ${ }^{8}$

Second, the appropriate balance to strike between precise determinism and broad generalizations, which results from Pareto's divide between economics and sociology, is relevant to the construction of modern fiscal theory. Specifically, Pareto's economics culminates in a deterministic result (e.g. the exact equilibrium point in commodity space is determinate if a logical means-ends applies applies) whereas his sociology only yields broad uniformities (e.g. the exact change in allocations attributed to fiscal redistribution is not determinate a priori, because a logical means-ends nexus does not apply, but the emergence of fiscal redistribution of some kind as a result of interactions between economic and political elites is predictable even when action is non-logical). The scientifically valid level of

\footnotetext{
${ }^{8}$ A Paretian explanation of Western Australian Government's public finances is presented in McLure (2017), which shows that the increase in revenue raising capacity from the millennium mineral boom led to a massive increase in net public debt because the Government treated a transitory increase in royalty and tax revenue as a permanent increase in its capacity to fund ongoing growth recurrent expenditures.
} 
determinism was a first order question to Pareto; and that same question should also be a first order question for modern fiscal theory.

Pareto's binary classification as either logical or non-logical may have been unnecessary restrictive when applied in all circumstances because it precludes a broader range of phenomena from logical and deductive analysis. Perhaps the balance lies elsewhere, but Pareto's concern with the limits of logical deductive theorizing on fiscal matters is as relevant today as it was when he lived. Curiously, Pareto's most prominent followers were Gino Borgatta (1920 [2007]) and Guido Sensini (1932 [2007]) and neither of these men adopted Pareto's extreme opposition to the science of public finance as a form of pure economics. They attempted to create more room for the economic theory of public finance than that permitted by Pareto, partly by suggesting that there are intermediate points between the binary poles of logical and non-logical action. Sensini, for example, felt that logical and non-logical actions were often 'mixed' in public finance, with some of those mixed actions being reasonably approximated by logical action. Borgatta adopted a similar line, wanting issues such as the incidence of taxation studied economically. In other words, they both accepted the importance of complementing the economics of public finance with fiscal sociology. There clearly appears to be greater scope for an economics of public finance than Pareto suggested, but his concern about the limits of strictly deductive analysis, and its nexus to the logical means-ends relationship, remains important for the scientific limits of modern deductive fiscal theory.

Third, Pareto’s focus on the means-ends relationship and its link between logical and non-logical action also serves to illustrate how precarious it is to consider the welfare of individuals in the collective as if the state were a collective entity. His sociological approach to collective maximization recognizes the practical need for the governing authorities to balance individuals' competing, and often inconsistent, views on social welfare. When Pareto addresses this issue, he does so in the full knowledge that he has converted an inherently non-logical system of relations into a quasi-logical arrangement (i.e. an arrangement whereby a 'logical' mean-ends nexus is forced) by imposing a politically determined welfare function. This process has the advantage of transparency, in that it makes it absolutely clear that the idea of a social welfare function depends, in the final analysis, on a politically imposed decision on the weights to be imposed on individual social preferences. As such, it suggests one comparative static resolution of the problem of individuals living 
collectively and, of course, scholars and policy makers are open to reject such a social welfare formulation for the very reason that it ultimately privileges the political decision required to form the welfare function. But reflection on how to resolve these problems, in light of Pareto’s attempted solution, is useful for modern fiscal theory.

Finally, Paretian fiscal sociology is a complement to the fiscal sociology that has been recently developed by Richard E. Wagner (2007) and Giuseppe Eusepi and Wagner (2011, 2013). They focus on the 'ecologies' of political enterprise and the associated action between and within the public and private squares. While the 'conjunctive' vision of the relationship between the market and the state portrayed by Wagner and Eusepi is not motivated by the ideas of Pareto, the sociological interconnection they associate with the theory of public finance can be incorporated with Pareto's broad sociological treatment of non-logical action. This is primarily the case because both approaches accept that the subjective phenomena impacts on the objective phenomena and vice-versa. As Wagner puts it, "I regard both mind and society as real categories of existence, in that society cannot be reduced to an individual even though society cannot exist without individuals” (2007, p. 21). This is entirely consistent with Pareto's core position, outlined in his “L'Individuale ed il Sociale” (Pareto 1904 [1980]).

Paretian fiscal sociology is more abstract than Wagner's and it has limited focus on entrepreneurs per se or enterprises. But Pareto’s discussion of the interrelationships between speculators and rentiers and political elites, using Pareto's speculators and rentiers, and his use of Machiavelli's analogy between foxes (as cunning political personalities who confront problems indirectly) and lions (as strong and principled politicians who confront issues directly) for the political equilibrium, are also broad enough to accommodate the more specific linkages between entrepreneurs, enterprises, the public square and the market square, as developed by Wagner and Eusepi. Furthermore, Pareto’s treatment of debt and political equilibrium as a balance between centripetal and centrifugal forces are also themes in Pareto's sociology that resonate with the approaches of Wagner and Eusepi to the topics of public debt and decentralization.

In short, Paretian fiscal sociology continues to offer a range of insights that are worthy of consideration by modern fiscal theorists. It also appears to constitute a suitable framework for the development of economically and politically oriented fiscal histories of national and/or subnational governments. 


\section{References}

Backhaus, J. 1978. “Pareto on Public Choice”, Public Choice, 33(1), pp. 5-17.

Borgatta, G. 2007. 'The Scientific Study of Fiscal Phenomena'. In The Paretian School and Italian Fiscal Sociology, edited by M. McLure. Houndmills Basingstoke: Palgrave Macmillan. Originally published in 1920 as 'Lo Studio Scientifico dei Fenomeni Finanziari’, Giornale degli Economisti e Rivista di Statistica 31(60), pp 1-24, 81116.

Buchanan, J. 1960. "'La Scienza delle Finanze': The Italian Tradition in Fiscal Theory", in James Buchanan, Fiscal Theory and Political Economy, Chapel Hill: The University of North Carolina Press: 24-74.

Buchanan, J. 1962 “The Relevance of Pareto Optimality”, Journal of Conflict Resolution, 6(4), pp. 341-354.

Busino, Giovanni 1994. "Prefazione”, in La Sociologia di Vilfredo Pareto e il Senso della Modernità, M-L Maniscalco. Milano: Franco Angeli, pp. 7-10.

Eusepi, G. and Wagner, R. E. 2011, States as Ecologies of Political Enterprises”, Review of Political Economy, 23, pp. 573-585.

Eusepi, G. and Wagner, R. E. 2013, “Tax Prices in a Democratic Polity: The Continuing Relevance of Antonio de Viti de Marco”, History of Political Economy, 45(1), pp. 99121.

Fausto, Domenicantonio 2006. “The Italian Approach to the Theory of Public Goods”, European Journal of the History of Economic Thought, 13(1), pp. 69-98

Fasiani, M 1980 [1932-33], 'La Teoria della Finanza Pubblica in Italia [Der gegenwärtige stand der reinen theorie der finanzwissenschaft in Italien]'. Il Pensiero Economico Italiano 1850-1950, Bologna: Cappelli: 117-202.

Fasiani, M 1949, “Contributi di Pareto alla Scienza delle Finanze”, Giornale degli Economisti e Annali di Economia, 8(3-4), pp. 129-73.

Fossati, Amedeo 2006. “Needs, the Principle of Minimum Means, and Public Goods in de Viti de Marco”, Journal of the History of Economic Thought, 28(4), pp. 427-443.

Higgins, Henry B. 1907. Ex parte H.V. McKay, Melbourne: Commonwealth Court of Conciliation and Arbitration, pp. 1-25 http://www.aph.gov.au/binaries/library/intguide/law/harvester.pdf 
Magnani, Italo (2008). “Note a Margine di una Recente Opera sull’Indirizzo Sociologico della Scienza delle Finanze Italiana”, Rivista di Diritto Finanziario e Scienza della Finanza, 67(2), pp. 165-99.

McLure, M 2010, “Pareto’s Chronicles: Liberty, the Left and Sociology”, Review of Political Economy, 22(3), pp. 439-458.

McLure, M 2007, The Paretian School and Italian Fiscal Sociology, Palgrave Macmillan, Houndmills Basingstoke.

McLure, M. 2017 “Ricardian Equivalence, the Italian Fiscal Tradition and Western Australia’s Government Net Debt”, Agenda, 24(1), pp. 5-20.

Olson, Mancur 1965. The Logic of Collective Action: Public Goods and the Theory of Groups, Cambridge MA: Harvard University Press.

Pareto, Vilfredo 1894. "Il Massimo di Utilità dato dalla Libera Concorenza” Giornale degli Economisti, 4(9), 48-66; translated into English by John Cairncross (and edited by John Chipman) as “The Maximum of Utility given by Free Competition”, Giornali degli Economisti e Annali di Economia, 67(3), December (2008), 387-403.

Pareto, V. [1896-97] 1971. Corso di Economia Politica [Cours d'Économie Politique], Torino: Unione Tipographico-Editrice Torinese.

Pareto, Vilfredo 1900a. "Sunto di Alcuni Capitoli di un Nuovo Trattato di Economia Pura del Prof. Pareto”, Giornali degli Economisti, 2(20), March and June 1900, 216-235 and 511-549, translated into English by John Cairncross (and edited by John Chipman) as 'Summary of Some Chapters of a New Treatise on Pure Economics by Professor Pareto', Giornali degli Economisti e Annali di Economia, 67(3), December (2008), pp. 453-504.

Pareto, Vilfredo 1900b. “Sul Fenomeno Economico”, Giornale degli Economisti, II, pp. 139162; translated as “On the Economic Phenomenon: a Reply to Benedetto Croce”, International Economic Papers, Vol. 3, 1953, London: Macmillan, pp. 180-196; and reproduced in Vilfredo Pareto: Critical Assessments, Vol. 1. 1999, London: Routledge, pp. 245-261.

Pareto, Vilfredo 1900c. “Un’Applicazione di Teoria Sociologiche”, July, pp. 401-456; reprinted in Vilfredo Pareto Euvres Complètes 22: Écrits Sociologiques Mineurs, Edited by Giovanni Busino, Genéve: Librairie Droz, 1980. pp. 178-238. 
Pareto, Vilfredo 1902. “Di un Nuovo Errore nello Interpretare le Teorie dell’Economia Matematica”, Giornale degli Economisti, 12(15), pp. 401-33; translated into English by John Cairncross (and edited by John Chipman) as 'On a New Error in the Interpretation of the Theories of Mathematical Economics', Giornali degli Economisti e Annali di Economia, 67(3), December (2008), pp. 515-544.

Pareto, V. [1902] 1974. I Sistemi Socialisti [Les Systèmes Socialistes], Torino: Unione Tipografico-Editrice Torinese.

Pareto, Vilfredo 1904. “L’Individuale ed il Sociale”, reprinted in Vilfredo Pareto Cuvres Complètes 22: Écrits Sociologiques Mineurs, Edited by Giovanni Busino, Genéve: Librairie Droz, 1980. pp. 268-278.

Pareto, Vilfredo [1906 and 1909]. 2014. Manual of Political Economy: A Critical and Variorum Edition, edited by A. Montesano, A. Zanni, L. Bruni, J. S. Chipman and M. McLure, (2014), Oxford: Oxford University Press.

Pareto, Vilfredo 1910. “Le Azioni Non Logiche’ Rivista Italiana di Sociologia”, MayAugust, pp. 305-364. reprinted in Vilfredo Pareto Euvres Complètes 22: Écrits Sociologiques Mineurs, Edited by Giovanni Busino, Genéve: Librairie Droz, 1980. pp. 345-408.

Pareto, V. [1913] 1980. “Il Massimo di Utilità per una Collettività in Sociologia”, Écrits Sociologiques Mineurs, Euvres Complètes, Genéve: Librairie Droz, 601-605.

Pareto, V. [1916] 1935. Mind and Society [Tratatto di Sociologia Generale], New York: Harcourt, Brace and Company.

Pareto, V. [1918] 1980. “Economia Sperimentale”, Écrits Sociologiques Mineurs, Euvres Complètes, Genéve: Librairie Droz, 719-43.

Pareto, V. 1975a. “A Guido Sensini” letter of 9 April 1905, in Giovanni Busino (ed) Correspondance, 19(2), Euvres Complètes, Genéve: Librairie Droz, 542-544.

Pareto, V. 1975c. “A Guido Sensini” letter of 5 April 1917, in Giovanni Busino (ed) Correspondance, 19(2), Euvres Complètes, Genéve: Librairie Droz, 958.

Scotto, A. 1950. “L’Opera Scientifica di Gino Borgatta”, Giornale degli Economisti e Annali di Economia, 9(9-10), 441-509.

Sensini, G 1932, La finanza sociologica. Studi di Scienze Sociali, (1), Roma: Casa Libraria Editrice Italiana: 232 - 52. 
Wagner, R. E. 2007. Fiscal Sociology and the Theory of Public Finance: An Exploratory Essay, Cheltenham: Edward Elgar. 
Editor, UWA Economics Discussion Papers:

Sam Hak Kan Tang

University of Western Australia

35 Sterling Hwy

Crawley WA 6009

Australia

Email: ecoadmin@biz.uwa.edu.au

The Economics Discussion Papers are available at:

1980 - 2002: $\quad$ http://ecompapers.biz.uwa.edu.au/paper/PDF\%20of\%20Discussion\%20Papers/

Since 2001: $\quad$ http://ideas.repec.org/s/uwa/wpaper1.html

Since 2004: $\quad$ http://www.business.uwa.edu.au/school/disciplines/economics

\begin{tabular}{|c|c|c|}
\hline \multicolumn{3}{|c|}{ ECONOMICS DISCUSSION PAPERS - 2016} \\
\hline $\begin{array}{l}\text { DP } \\
\text { NUMBER }\end{array}$ & AUTHORS & TITLE \\
\hline 16.01 & Xu, R., Wu, Y. and Luan, J. & $\begin{array}{l}\text { ANALYSIS OF FARMERS’ WILLINGNESS TO ADOPT } \\
\text { GENETICALLY MODIFIED INSECT-RESISTANT RICE IN } \\
\text { CHINA }\end{array}$ \\
\hline 16.02 & $\begin{array}{l}\text { Lia, Y., Fan, J., Zhao, D., Wu, Y. and } \\
\text { Li, J. }\end{array}$ & $\begin{array}{l}\text { TIERED GASOLINE PRICING: A PERSONAL CARBON } \\
\text { TRADING PERSPECTIVE }\end{array}$ \\
\hline 16.03 & Clements, K.W., Lan, Y. and Si, J. & UNCERTAINTY IN CURRENCY MISPRICING \\
\hline 16.04 & Parsons, C. and Vézina, P.L. & $\begin{array}{l}\text { MIGRANT NETWORKS AND TRADE:THE VIETNAMESE } \\
\text { BOAT PEOPLE AS A NATURAL EXPERIMENT }\end{array}$ \\
\hline 16.05 & Chang, S., Connelly, R. and Ma, P. & $\begin{array}{l}\text { WHAT WILL YOU DO IF I SAY 'I DO’?: THE EFFECT OF } \\
\text { THE SEX RATIO ON TIME USE WITHIN TAIWANESE } \\
\text { MARRIED COUPLES }\end{array}$ \\
\hline 16.06 & Yu, F. and Wu, Y. & $\begin{array}{l}\text { BIASES IN PATENT EXAMINATION AND FIRMS’ } \\
\text { RESPONSES: EVIDENCE FROM THE } \\
\text { PHARMACEUTICAL INDUSTRY }\end{array}$ \\
\hline 16.07 & $\begin{array}{l}\text { Fan, J., Li, J., Wu, Y., Wang, S. and } \\
\text { Zhao, D. }\end{array}$ & $\begin{array}{l}\text { THE EFFECTS OF ALLOWANCE PRICE ON ENERGY } \\
\text { DEMAND UNDER A PERSONAL CARBON TRADING } \\
\text { SCHEME }\end{array}$ \\
\hline 16.08 & Golley, J., Tyers, R. and Zhou, Y. & $\begin{array}{l}\text { CONTRACTIONS IN CHINESE FERTILITY AND } \\
\text { SAVINGS: LONG RUN DOMESTIC AND GLOBAL } \\
\text { IMPLICATIONS }\end{array}$ \\
\hline 16.09 & McGrath, G. and Neill, K. & $\begin{array}{l}\text { FOREIGN AND DOMESTIC OWNERSHIP IN WESTERN } \\
\text { AUSTRALIA'S GAS MARKET }\end{array}$ \\
\hline 16.10 & Clements, K.W. and Si, J. & SIMPLIFYING THE BIG MAC INDEX \\
\hline 16.11 & Priyati, R.Y. and Tyers, R. & $\begin{array}{l}\text { PRICE RELATIONSHIPS IN VEGETABLE OIL AND } \\
\text { ENERGY MARKETS }\end{array}$ \\
\hline 16.12 & Wu, J., Wu, Y. and Wang, B. & $\begin{array}{l}\text { THE GREENNESS OF CHINESE CITIES: CARBON } \\
\text { DIOXIDE EMISSION AND ITS DETERMINANTS }\end{array}$ \\
\hline 16.13 & $\begin{array}{l}\text { Arslan, C., Dumont, J.C., Kone, Z., } \\
\text { Özden, Ç., Parsons, C. and } \\
\text { Xenogiani, T. }\end{array}$ & $\begin{array}{l}\text { INTERNATIONAL MIGRATION TO THE OECD IN THE } \\
\text { TWENTY-FIRST CENTURY }\end{array}$ \\
\hline 16.14 & Tomioka, K. and Tyers, R. & $\begin{array}{l}\text { HAS FOREIGN GROWTH CONTRIBUTED TO } \\
\text { STAGNATION AND INEQUALITY IN JAPAN? }\end{array}$ \\
\hline
\end{tabular}




\begin{tabular}{|c|c|c|}
\hline 16.15 & Donovan, J. and Hartley, P. & $\begin{array}{l}\text { RIDING THE IRON ORE CYCLE: ACTIONS OF } \\
\text { AUSTRALIA'S MAJOR PRODUCERS }\end{array}$ \\
\hline 16.16 & Czaika, M. and Parsons, C. & $\begin{array}{l}\text { HIGH-SKILLED MIGRATION IN TIMES OF GLOBAL } \\
\text { ECONOMIC CRISIS }\end{array}$ \\
\hline 16.17 & Lefroy, T., Key, J. and Kingwell, R. & $\begin{array}{l}\text { A LONGITUDINAL EXAMINATION OF BROADACRE } \\
\text { FARM SIZE AND PERFORMANCE IN WESTERN } \\
\text { AUSTRALIA }\end{array}$ \\
\hline 16.18 & Arthmar, R. and McLure, M. & $\begin{array}{l}\text { SRAFFA, MYRDAL AND THE } 1961 \text { SÖDERSTRÖM GOLD } \\
\text { MEDAL }\end{array}$ \\
\hline 16.19 & Azwar, P. and Tyers, R. & $\begin{array}{l}\text { POST-GFC EXTERNAL SHOCKS AND INDONESIAN } \\
\text { ECONOMIC PERFORMANCE }\end{array}$ \\
\hline 16.20 & Chen, A. and Groenewold, N. & $\begin{array}{l}\text { OUTPUT SHOCKS IN CHINA: DO THE DISTRIBUTIONAL } \\
\text { EFFECTS DEPEND ON THE REGIONAL SOURCE? }\end{array}$ \\
\hline 16.21 & Wu, Y., Zhu, X. and Groenewold, N. & $\begin{array}{l}\text { THE DETERMINANTS AND EFFECTIVENESS OF } \\
\text { INDUSTRIAL POLICY IN CHINA: A STUDY BASED ON } \\
\text { FIVE-YEAR PLANS }\end{array}$ \\
\hline 16.22 & Liu, H. & $\begin{array}{l}\text { THE INCOME AND PRICE SENSITIVITY OF DIETS } \\
\text { GLOBALLY }\end{array}$ \\
\hline 16.23 & Asano, A., Neill, K. and Yamazaki, S. & $\begin{array}{l}\text { DECOMPOSING FISHING EFFORT: MODELLING THE } \\
\text { SOURCES OF INEFFICIENCY IN A LIMITED-ENTRY } \\
\text { FISHERY }\end{array}$ \\
\hline 16.24 & Golley, J., Tyers, R. and Zhou, Y. & $\begin{array}{l}\text { FERTILITY AND SAVINGS CONTRACTIONS IN CHINA: } \\
\text { LONG-RUN GLOBAL IMPLICATIONS }\end{array}$ \\
\hline 16.25 & Taylor, G., Tyers, R. & $\begin{array}{l}\text { SECULAR STAGNATION: DETERMINANTS AND } \\
\text { CONSEQUENCES FOR AUSTRALIA }\end{array}$ \\
\hline
\end{tabular}

\begin{tabular}{|c|c|c|}
\hline \multicolumn{3}{|c|}{ ECONOMICS DISCUSSION PAPERS - 2017} \\
\hline $\begin{array}{l}\text { DP } \\
\text { NUMBER }\end{array}$ & AUTHORS & TITLE \\
\hline 17.01 & Tyers, R. and Zhou, Y. & $\begin{array}{l}\text { AUTOMATION AND INEQUALITY WITH TAXES AND } \\
\text { TRANSFERS }\end{array}$ \\
\hline 17.02 & Ye, L. and Robertson, P. & $\begin{array}{l}\text { HITTING THE GREAT WALL: RURAL-URBAN } \\
\text { MIGRATION AND CHINA'S GROWTH SLOWDOWN }\end{array}$ \\
\hline 17.03 & Ye, L. and Robertson, P. & $\begin{array}{l}\text { MIGRATION AND GROWTH IN CHINA: A SCEPTICAL } \\
\text { ASSESSMENT OF THE EVIDENCE }\end{array}$ \\
\hline 17.04 & Clements, K. Si, J. and Vo, L. & $\begin{array}{l}\text { FOOD AND AGRICULTURAL PRICES ACROSS } \\
\text { COUNTRIES AND THE LAW OF ONE PRICE }\end{array}$ \\
\hline 17.05 & $\begin{array}{l}\text { Chen, M., Clements, K., Gao, G. and } \\
\text { Si, J. }\end{array}$ & THREE FACTS ABOUT WORLD METAL PRICES \\
\hline 17.06 & $\begin{array}{l}\text { Cornes, R., Fiorini, L. and } \\
\text { Maldonado, W. }\end{array}$ & $\begin{array}{l}\text { EXPECTATIONAL STABILITY IN AGGREGATIVE } \\
\text { GAMES }\end{array}$ \\
\hline 17.07 & Hartley, P. & $\begin{array}{l}\text { THE COST OF DISPLACING FOSSIL FUELS: SOME } \\
\text { EVIDENCE FROM TEXAS }\end{array}$ \\
\hline 17.08 & Shehabi, M. R. & ASSESSING KUWAITI ENERGY PRICINING REFORMS \\
\hline 17.09 & Perdana, S. and Tyers, R. & $\begin{array}{l}\text { GLOBAL CLIMATE CHANGE MITIGATION: STRATEGIC } \\
\text { INTERACTION OR UNILATERAL GAINS? }\end{array}$ \\
\hline 17.10 & McLure, M. & $\begin{array}{l}\text { RICARDIAN EQUIVALENCE, THE ITALIAN FISCAL } \\
\text { TRADITION AND WA GOVERNMENT NET DEBT }\end{array}$ \\
\hline 17.11 & Trinh, J. & $\begin{array}{l}\text { THE PARETO DISTRIBUTION AND ITS RELATIONSHIP } \\
\text { TO PIKETTY'S THIRD FUNDAMENTAL LAW OF } \\
\text { CAPITALISM }\end{array}$ \\
\hline
\end{tabular}




\begin{tabular}{|c|c|c|}
\hline 17.12 & McLure, M. & $\begin{array}{l}\text { THINKING OUTSIDE THE BOX: A NEW HISTORY OF } \\
\text { EDGEWORTH'S AND PARENTO'S DEVELOPMENT OF } \\
\text { THE BOX DIAGRAM }\end{array}$ \\
\hline 17.13 & Zhou, Y. and Tyers, R. & AUTOMATION AND INEQUALITY IN CHINA \\
\hline 17.14 & Arthmar, R. and McLure, M. & $\begin{array}{l}\text { THE ECONOMIC AND SOCIAL CONSEQUENCES OF THE } \\
\text { WAR: PIGOU, THE PRESS AND THE STRUGGLE FOR AN } \\
\text { HONOURABLE PEACE }\end{array}$ \\
\hline 17.15 & Shehabi, M. R. & $\begin{array}{l}\text { CONTEMPORARY KUWAITISATION DYNAMICS AND } \\
\text { THEIR HISTORICAL PERSPECTIVES }\end{array}$ \\
\hline 17.16 & Clements, K. and Si, J. & $\begin{array}{l}\text { WHAT DO AUSTRALIAN ECONOMICS PhDs DO? THE } \\
\text { UWA EXPERIENCE }\end{array}$ \\
\hline 17.17 & Arthmar, R. and McLure, M. & KEYNES AND THE ROYAL SWEDISH ACADEMY \\
\hline 17.18 & Chen, A. and Groenewold, N. & $\begin{array}{l}\text { CHINA'S ‘NEW NORMAL’: IS THE GROWTH } \\
\text { SLOWDOWN DEMAND- OR SUPPLY- DRIVEN? }\end{array}$ \\
\hline 17.19 & Groenewold, N. & $\begin{array}{l}\text { CHINA'S ‘NEW NORMAL’: HOW WILL CHINA’S } \\
\text { GROWTH SLOWDOWN AFFECT AUSTRALIA’S } \\
\text { GROWTH? }\end{array}$ \\
\hline
\end{tabular}

\begin{tabular}{|l|l|l|}
\hline \multicolumn{2}{|c|}{ ECONOMICS DISCUSSION PAPERS - 2018 } \\
\hline $\begin{array}{c}|c| \\
\text { DP }\end{array}$ & \multicolumn{1}{|c|}{ AUTHORS } \\
\hline 18.01 & Tyers, R. and Zhou, Y. & TITLE \\
\hline 18.02 & McLure, M. & LOST INFLATION? \\
\hline 18.03 & McLure, M. and Montesano, A. & PARETIAN FISCAL SOCIOLOGY \\
\cline { 1 - 2 } & THINKING OUTSIDE THE BOX: EDGEWORTH, PARETO \\
\hline 18.04 & Tyers, R. and Zhou, Y. & DEFLATHE EARLY HISTORY OF THE BOX DIAGRAM \\
\hline
\end{tabular}

